\title{
2D Film of Carbon Nanofibers Elastically Astricted MnO microparticles: A Flexible Binder-Free Anode for Highly Reversible Lithium Ion Storage
}

Ting Wang, Hangang Li, Shaojun Shi, Ting Liu, Gang Yang*, Yimin Chao*, and Fan Yin

T. Wang, H. Li, Dr. S. Shi, T Liu, Prof. G. Yang

Jiangsu Laboratory of Advanced Functional Material, School of Chemistry and Materials Engineering, Changshu Institute of Technology, Changshu 215500, P. R. China

Email: gyang@cslg.edu.cn

Dr. Y. Chao

Energy Materials Laboratory, School of Chemistry, University of East Anglia, Norwich NR4 7TJ, UK

Email: y.chao@uea.ac.uk

Prof. F. Yin

Jiangsu Laboratory of Advanced Functional Material, School of Chemistry and Materials Engineering, Changshu Institute of Technology, Changshu 215500, P. R. China

Keywords: lithium-ion batteries; flexible films; binder-free anode materials; composite structure; electrochemical performance. 


\section{Abstract:}

$\mathrm{MnO}$ as anode materials has received particular interest owing to its high specific capacity, abundant resources and low cost. However, it is still a serious problem that large volume change (>170\%) during the lithiation/delithiation processes results in poor rate capability and fast capacity decay. With homogenous crystals of $\mathrm{MnO}$ grown in the network of carbon nanofibers(CNF), binding effect of CNFs can effectively weaken the volume change of $\mathrm{MnO}$ during cycles. In this work, $\mathrm{CNF} / \mathrm{MnO}$ flexible electrode for lithium-ion batteries is designed and synthesized. The carbon nanofibers play the roles of conductive channel and elastically astricting $\mathrm{MnO}$ particles during lithiation/delithiation. $\mathrm{CNF} / \mathrm{MnO}$ as binder-free anode delivers specific capacity of $983.8 \mathrm{mAh} \mathrm{g}^{-1}$ after $100^{\text {th }}$ cycle at a current density of $0.2 \mathrm{~A} \mathrm{~g}^{-1}$, and 600 $\mathrm{mAh} \mathrm{g}^{-1}$ at $1 \mathrm{~A} \mathrm{~g}^{-1}$ which are much better than those of pure $\mathrm{MnO}$ and pure CNF. The ex-situ FESEM images of $\mathrm{CNF} / \mathrm{MnO}$ clearly show the relative volume change of $\mathrm{MnO} / \mathrm{CNF}$ as anode under various discharging and charging time. CNFs can elastically buffer the volume change of $\mathrm{MnO}$ during charging/discharging cycles. This work presents a facile and scalable approach for synthesizing a novel flexible binder-free anode of $\mathrm{CNF} / \mathrm{MnO}$ for potential application in highly reversible lithium storage devices. 


\section{Introduction}

Lithium-ion batteries (LIBs) possess increasing applications in electric vehicles and electricity storage stations after been widely used in portable electronic devices and electric tools. ${ }^{[1]}$ Currently, commercialized graphite is the most widely used anode material for LIBs, but it cannot meet the requirements for high-energy-density batteries due to its relatively low theoretical specific capacity $\left(372 \mathrm{mAh} \mathrm{g}^{-1}\right)$ and serious safety issues. ${ }^{[2]}$ Therefore, the ongoing effort to find alternative anode materials with high specific capacity and good cycling stability has become intensive interest in research community worldwide.

Transition metal oxides $\left(\mathrm{M}_{\mathrm{x}} \mathrm{O}_{\mathrm{y}} ; \mathrm{M}=\mathrm{Sn}, \mathrm{Ti}, \mathrm{Fe}, \mathrm{Co}, \mathrm{Ni}, \mathrm{Mn}, \mathrm{Mo}\right.$, etc. $)$ have been widely studied as potiential anode for LIBs. ${ }^{[3]}$ Among these transition metal oxides, manganese oxides $(\mathrm{MnO})_{\chi}$, have received extensive research interest due to their relatively low thermodynamic equilibrium voltage versus $\mathrm{Li} / \mathrm{Li}^{+}$, as well as their environmental benignity, low cost and greatnatural abundance. ${ }^{[4]}$ However, $\mathrm{MnO}_{x}$ suffers from a large volumetric variation and gradual agglomeration of metal grains that result in rapid capacity decreasing and the poor rate capability during the charge/discharge processes. To address these critical challenges, earlier researchers have done excellent work on $\mathrm{MnO}_{x}$ through graphene modification, carbon coating or carbon nanofiber loading for LIBs to suppress the pulverization problem and capacity decreasing. ${ }^{[5]}$

More recently, flexible electrodes includes the anodes of $\mathrm{MnO}_{\mathrm{x}}$ have been attractive for high-performance energy storage devices. ${ }^{[6]}$ In conventional processing of electrodes, the active materials are usually attached to the current collectors using poly(vinylidene fluoride) (PVDF) as binder, solvent of N-methyl-2-pyrrolidone (NMP) and conductive additives (carbon black) for improving mechanical adhesion and electrical contact. However, the 
Carbon nanofibers (CNFs) are potential substrate for flexible electrodes. There are many reports in literature that metal oxide has been embedded in CNFs synthesized by electrospinning/carbonization. ${ }^{[4 b, 5 \mathrm{~d}, 9]}$ The typical procedures include electrospinning and high heat-treatment, crystal growth of metal oxide and simultaneous carbonization of polyacrylonitrile (PAN) to form composite film of metal oxide embedded in CNF. ${ }^{[10]}$ Although the built-in structure of the composite is still not good for high-performance LIBs, CNF film is an applicable multi-level network with micrometers free space for loading metal oxide particles. Importantly, CNFs play the roles of good conductive channel, ${ }^{[96,11]}$ and strapping the particles of metal oxide to constrain the volume change during lithiation/delithiation.

In this work, flexible CNF film has firstly been synthesized by electrospinning and carbonization, and then $\mathrm{MnO}$ particles are grown on CNFs and are strapped in the matrix of CNFs through hydrothermal method. The produced flexible film of metal oxide@CNF is flexible and could be used as binder-free anode without using traditional polymeric binder, conductive carbon and metal current collector, in which the energy density of electrode is 
much higher than that of pure metal oxide. Owing to the unique flexible hybrid structure, the as-prepared $\mathrm{CNF} / \mathrm{MnO}$ served as an anode for LIBs exhibits high reversible capacity, excellent rate and cycling performance.

\section{Results and Discussion}

\subsection{Structure and Morphology}

The crystal morphologies of pure $\mathrm{MnO}$ and composite of $\mathrm{CNF} / \mathrm{MnO}$ are shown in Figure 1

Pure $\mathrm{MnO}$ is green colored powder and cubic microcrystals (Figure 1 a). The average crystal size of $\mathrm{MnO}$ is about $10 \mu \mathrm{m}$. Based on the high-magnified SEM image, $\mathrm{MnO}$ microcrystal is close packed by nano-crystallites. Poor conductivityis predicted in the micro-sized $\mathrm{MnO}$ because the crystal structure is too large and full of nanopores among crystallites. If CNF film is presented in the reaction system of $\mathrm{MnO}, \mathrm{CNF}$ plays a large effect in the crystal growth of $\mathrm{MnO}$ (as shown the SEM image in Figure $\mathbf{1 b}$ and $\mathbf{1 b}$ ). Homogeneous cubic nanocrystals $\mathrm{MnO}$ particles grow on $\mathrm{CNF}$, and the crystal size of $\mathrm{MnO}$ is about $2 \mu \mathrm{m}$ in $\mathrm{CNF} / \mathrm{MnO}$, much smaller than $10 \mu \mathrm{m}$ in pure $\mathrm{MnO}$ sample. Millimeter sized $\mathrm{CNF} / \mathrm{MnO}$ is a black colored flexible film, which can be directly applied as binder-free anode assembled in LIBs. The SEM image (Figure $1 \mathrm{~b}$ ) of $\mathrm{CNF} / \mathrm{MnO}$ film presents many free spaces within the three-dimensional (3D) matrix which providesufficient area for the growth of metal oxides. Figure 1c shows the XRD patterns of pure CNFs film, pure $\mathrm{MnO}$ powder and CNF/MnO film. Pure CNF film

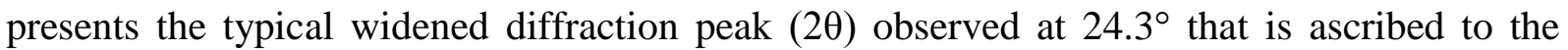
characteristic peak of graphite structure ${ }^{[12]}$ All the diffraction peaks of pure $\mathrm{MnO}$ powder can be readily indexed to cubic $\mathrm{MnO}$ (JCPDS No. 07-0230). The XRD patterns of CNF/MnO exhibit the combination of $\mathrm{MnO}$ and $\mathrm{CNFs}$ film without any impurities. A weak diffraction peak observed at $24.3^{\circ}$ of $\mathrm{CNF} / \mathrm{MnO}$ indicates that $\mathrm{CNFs}$ maintain graphitization structure during hydrothermal and calcination processes. The elemental mapping images of $\mathrm{CNF} / \mathrm{MnO}$ 
further reveal $\mathrm{MnO}$ particles inside the CNFs matrix. $\mathrm{C}, \mathrm{O}$ and $\mathrm{Mn}$ elements are properly dispersed in CNFs and $\mathrm{MnO}$, respectively (Figure 1 $\left.\mathrm{c}^{\prime}\right)$. The carbon content by elemental analysisis calculated as $30.66 w t \%$ in $\mathrm{CNF} / \mathrm{MnO}$, corresponding to weight ratio of $\mathrm{CNF}: \mathrm{MnO}$ $1: 1.5$. The weight load of $\mathrm{MnO}$ in the flexible films of $\mathrm{CNF} / \mathrm{MnO}$ is much higher than that of other composite film using carbon paper, carbon cloth or nickel foam as substrate. ${ }^{[7 a, b, c, 13]}$

The TEM images show that $\mathrm{MnO}$ crystals have closely grownaround carbon nanofibers (Figure S1a and S1b). Main crystal of MnO is a single crystal as shown in HR-TEM image of $\mathrm{MnO}$ (Figure S1c). The lattice spacing between fringes of $\mathrm{MnO}$ in the film $\mathrm{CNF} / \mathrm{MnO}$ can be resolved as $0.25 \mathrm{~nm}$ (Figure S1c), agreeing well with inter planar spacing of (111) planes of $\mathrm{MnO}^{[14]}$ At the edge between $\mathrm{CNF}$ and $\mathrm{MnO}$, minor $\mathrm{MnO}$ crystallites are dispersed on the surface of CNFs (Figure S1d). X-ray photoelectron spectra (XPS) of CNF/MnO show the presence of C, N, O and Mn elements without any impurities (Figure S2). The high-resolution spectrum of C 1s can be revolved into three peaks centered at 284.8, 286.2 and $288.3 \mathrm{eV}$, respectively. The main peak at $284.8 \mathrm{eV}$ belongs to the $\mathrm{sp}^{2}$-hybridized graphite carbon. ${ }^{[15]}$ Two weak peaks at 286.2 and $288.3 \mathrm{eV}$ belong to $\mathrm{C}-\mathrm{O}$ and $\mathrm{C}=\mathrm{O}$, respectively. ${ }^{[16]}$ The $\mathrm{N} 1 \mathrm{~s}$ core-level spectrum can be well fitted into a pyrodinic nitrogen (N-6) at $398.4 \mathrm{eV}$ and a pyrrolic nitrogen (N-5) at $400.4 \mathrm{ev}^{[17]}$ The presence of $\mathrm{C}, \mathrm{N}$ elements observed in $\mathrm{CNF} / \mathrm{MnO}$ are in accordance with CNFs produced by PAN. The binding energy of O1s obtained here are $529.9 \mathrm{eV}$ and $531.5 \mathrm{eV}$ that can be assigned to $\mathrm{Mn}-\mathrm{O}$ and $\mathrm{C}-\mathrm{O}$ bonding, respectively. The oxidation state of Mn determined by analyzing the spin energy separation of Mn 3s doublet spectrum, exhibits a typical spin energy separation of $5.9 \mathrm{eV}$ corresponding to $\mathrm{Mn}(\mathrm{II}){ }^{[18]}$ The high-resolution spectra of Mn2p exhibit two peaks at $641.5 \mathrm{eV}$ for $\mathrm{Mn} 2 \mathrm{p}_{3 / 2}$ and $653.2 \mathrm{eV}$ for Mn 2 $\mathrm{p}_{1 / 2}$, respectively, which are also consistent with those of $\mathrm{MnO}$.

\subsection{Electrochemical Performance}


The flexible film of CNF/MnO is directly assembled in LIBs without using any polymeric binders, conductive additives or current collector. The $\mathrm{CV}$ profiles of $\mathrm{CNF} / \mathrm{MnO}$ are shown in Figure 2a. A weak reduction peak at $0.5 \mathrm{~V}$ is ascribed to the formation of solid electrolyte interface (SEI) layers. ${ }^{[19]}$ The sharp reduction peak closed to $0.1 \mathrm{~V}$ in the first sweep is ascribed to the reduction of $\mathrm{Mn}^{2+}$ to $\mathrm{Mn}^{0}$. This peak shifts to $0.3 \mathrm{~V}$ in the following cycles, suggesting an irreversible phase transformation due to the formation of $\mathrm{Li}_{2} \mathrm{O}$ and metallic manganese ${ }^{[20]} \mathrm{A}$ wide peak around $1.3 \mathrm{~V}$ appearing in anodic sweep is ascribed to the oxidation of $\mathrm{Mn}(0)$ to $\mathrm{Mn}(\mathrm{II}){ }^{[21]}$ The profiles of CVs in the subsequent sweep are overlapped very well except the initial sweep, demonstrating the excellent reversibility of the electrochemical reactions happened in the electrode $\mathrm{CNF} / \mathrm{MnO}$. GITT technique based on chronopotentiometry has been carried out to study the diffusion ability of lithium ions during charge/discharge processes. ${ }^{[22]}$ According to the GITT curves (Figure 2b), the $\mathrm{DLi}^{+}$values of pure $\mathrm{MnO}$ and $\mathrm{CNF} / \mathrm{MnO}$ are calculated and plotted in Figure 2c, $2 \mathbf{2 d}$. In the discharge process, the $\mathrm{D}_{\mathrm{Li}}{ }^{+}$rapidly decreases to the minimum at $0.7 \mathrm{~V}$ and then rapidly increases back. Pure $\mathrm{MnO}$ presents much lower $\mathrm{DLi}_{\mathrm{Li}}^{+}$than $\mathrm{CNF} / \mathrm{MnO}$, especially the $\mathrm{DLi}^{+}$of $\mathrm{MnO}$ is lower than that of $\mathrm{CNF} / \mathrm{MnO}$ three orders of magnitude at $0.7 \mathrm{~V}$ (Figure 2c). In charge process, pure $\mathrm{MnO}$ also appears lower $\mathrm{DLi}^{+}$than $\mathrm{CNF} / \mathrm{MnO}$ (Figure 2d). It further confirms that CNFs not only provides conductive channel but also enhances the contact between $\mathrm{MnO}$ particles and electrolyte improving the diffusion ability of $\mathrm{Li}^{+}$during lithiation/delithiation processes.

The charge-discharge profiles of $\mathrm{CNF} / \mathrm{MnO}$, pure $\mathrm{MnO}$ and pure $\mathrm{CNF}$ at a current density of $0.2 \mathrm{~A} \mathrm{~g}^{-1}$ between 0.001 and $3.0 \mathrm{~V}$ are displayed in Figure 3a. The initial discharge capacities of pure $\mathrm{MnO}$, pure $\mathrm{CNF}$ and $\mathrm{CNF} / \mathrm{MnO}$ are $933.1,595.3$ and $1308.3 \mathrm{mAh} \mathrm{g}^{-1}$, respectively. The specific capacity of $\mathrm{CNF} / \mathrm{MnO}$ is calculated by using the following equation. ${ }^{[23]}$

$$
\mathrm{C} \mathrm{CNF} / \mathrm{MnO}=\mathrm{C} \mathrm{MnO} \times \% \text { mass of } \mathrm{MnO}+\mathrm{C} \text { CNFs } \times \% \text { mass of } \mathrm{CNFs}
$$


As shown in Figure 3a, the initial Coulombic efficiencies of pure $\mathrm{MnO}$, pure $\mathrm{CNF}$ and $\mathrm{CNF} / \mathrm{MnO}$ are $50 \%, 62 \%$ and $67 \%$, respectively. Capacity losses in the first cycle appeared in the three samples are mainly attributed to the irreversible processes such as electrolyte decomposition and inevitable formation of the solid electrolyte interphase (SEI) layer, ${ }^{[24]}$ but the columbic efficiency of $\mathrm{CNF} / \mathrm{MnO}$ is close to $100 \%$ after the initial cycles. After the first lithiation, the SEI layer covers the surface of $\mathrm{MnO}$ particles which hinders the direct contact between the resulting nanoclusters of $\mathrm{Mn}$ and the electrolyte. ${ }^{[25]}$ Moreover, $\mathrm{CNF} / \mathrm{MnO}$ shows excellent cycling stability (Figure 3b). At the $50^{\text {th }}$ cycle, $\mathrm{CNF} / \mathrm{MnO}$ remains a capacity of 992.3 $\mathrm{mAh} \mathrm{g}^{-1}$, but the capacity decreases to $332.1 \mathrm{mAh} \mathrm{g}^{-1}$ for pure $\mathrm{MnO}$ and $280 \mathrm{mAh}$ $\mathrm{g}^{-1}$ forpure $\mathrm{CNF}$, respectively. Under various current densities, $\mathrm{CNF} / \mathrm{MnO}$ presents best rate performance than those of pure $\mathrm{MnO}$ and pure CNF, respectively (Figure 3c). The capacities for $\mathrm{CNF} / \mathrm{MnO}$ at $0.05,0.2$ and $1 \mathrm{~A} \mathrm{~g}^{-1}$ are 1004.4, 948.4, and 646.0mAh g${ }^{-1}$, respectively. However, both pure $\mathrm{MnO}$ and pure $\mathrm{CNF}$ electrodes only deliver $195 \mathrm{mAh} \mathrm{g}^{-1}$ at the current density of $1 \mathrm{~A} \mathrm{~g}^{-1}$. A capacity of $1318 \mathrm{mAh} \mathrm{g}^{-1}$ can be restored after another 25 cycles when the rate performed with $\mathrm{CNF} / \mathrm{MnO}$ electrode goes back to $0.05 \mathrm{~A} \mathrm{~g}^{-1}$. The excellent specific capacity, cyclic stability and rate performance, can be attributed to the synergetic structure of $\mathrm{CNF} / \mathrm{MnO}$ in which CNFs provide excellent conductive channel improving the specific capacity and effective matrix buffering the volume change to promote the cyclic performance. The comparison in electrochemical properties between $\mathrm{CNF} / \mathrm{MnO}$ and other related works has been summarized in Table S1 (in Supporting Information).

Electrochemical impedance spectroscopy (EIS) of $\mathrm{MnO}$ and $\mathrm{CNF} / \mathrm{MnO}$ carried out at the states of the $4^{\text {th }}$ and $20^{\text {th }}$ discharge is shown in Figure 4 with fittings on the basis of an equivalent circuit model (the inset in Figure 4b). The intercept of the high-frequency semicircle on the $Z^{\prime}$ axis is attributed to the resistance of electrolyte $\left(R_{s}\right)$. The high-frequency semicircle corresponds to the SEI layer resistance (RSEI). The middle-frequency semicircle is 
associated with the charge transfer resistance $\left(R_{c t}\right)$ and the electric resistance $\left(R_{e}\right)$. The $45^{\circ}$ slope line is generally defined as Warburg impedance $\left(Z_{w}\right)$ at low frequency, denoting the resistance caused by ion diffusion. ${ }^{[26]}$ The fitted EIS parameters are listed in Table 1 . The resistances of $\mathrm{CNF} / \mathrm{MnO}$ are lower than those of pure $\mathrm{MnO}$. For example, $\mathrm{R}_{\mathrm{ct}}$ of $\mathrm{CNF} / \mathrm{MnO}$ is $27.42 \mathrm{ohms}$ much lower than $96.98 \mathrm{ohms}$ of $\mathrm{MnO}$ at the state of discharged fourth cycles. CNF matrix plays the important role of improving the conductivity of $\mathrm{MnO}$ particles. For more cycles, the resistances of $\mathrm{R}_{\text {sei }}, \mathrm{R}_{\mathrm{e}}, \mathrm{R}_{\mathrm{ct}}$ and $\mathrm{W}-\mathrm{r}$ of $\mathrm{MnO}$ are all increased from 8.596, $35.68,96.98$ and $183.6 \mathrm{ohms}$ at the $4^{\text {th }}$ cycle, to $84.1,138.5,3660$ and $200.6 \mathrm{ohms}$ at the $20^{\text {th }}$ cycle. However, the resistances of $\mathrm{R}_{\text {sei, }}, \mathrm{R}_{\mathrm{e}}, \mathrm{R}_{\mathrm{ct}}$ and W-r of CNF/MnO present minor change after dozens of cycles, 8.704, 27.16, 27.42 and $96.1 \mathrm{ohms}$ at the $4^{\text {th }}$ cycle, and $12.73,9.614$, 40.9 and 103.6 ohms at the $20^{\text {th }}$ cycle, respectively. The structure of CNFs bound $\mathrm{MnO}$ particles (the inset of Figure 4a) efficiently locks and stabilizes $\mathrm{MnO}$ during charge/discharge processes. The flexible spaces within the CNFs matrix buffer the volume change of $\mathrm{MnO}$ during lithiation/delithiation cycles.

\subsection{Charge-Discharge Process of Hybrid Composites}

FESEM images of $\mathrm{CNF} / \mathrm{MnO}$ electrodes at various lithiation/delithiation states clearly demonstrate the effect of CNFs strapping MnO particles. In Figure 5, ex-situ FESEM images are shown from four CNF/MnO electrodes discharged for $1 \mathrm{~h}, 3 \mathrm{~h}, 9 \mathrm{~h}$, and $14 \mathrm{~h}$, respectively. It is clearly observed that $\mathrm{MnO}$ crystals remain completely particles morphology during discharge process. With the increased discharge time, $\mathrm{MnO}$ crystals display sizes at 2.39, 3.32, 3.57, and $5.01 \mu \mathrm{m}$ after discharged for $1 \mathrm{~h}, 3 \mathrm{~h}, 9 \mathrm{~h}$, and $14 \mathrm{~h}$, respectively. Carbon nanofibers like elastic ropes to strap the enlarged $\mathrm{MnO}$ particles, avoiding the pulverization of $\mathrm{MnO}$ particles. The elemental mappings of $\mathrm{CNF} / \mathrm{MnO}$ film reveal a homogeneous distribution of $\mathrm{C}$, $\mathrm{O}$ and $\mathrm{Mn}$ elements, indicating a stability of both hybrid structure and composition of 
$\mathrm{CNF} / \mathrm{MnO}$ electrode. Minor F element appeared on the surface of $\mathrm{MnO}$ particles due to the formation of SEI film.

To find the reversible volume change of $\mathrm{CNF} / \mathrm{MnOanode}$ during charging processes, FESEM images shown in Figure 6 are from another set of four CNF/MnO anodes charged for 6 h, 8 h, $9 \mathrm{~h}$, and $13 \mathrm{~h}$, respectively. With the increased charging time, $\mathrm{MnO}$ crystals dispersed in $\mathrm{CNF}$ matrix present the gradually decreased particle size, $4.95,3.47,2.65$ and $2.44 \mu \mathrm{m}$, respectively. Flexible carbon nanofibers still strap $\mathrm{MnO}$ particles. The elemental mappings of $\mathrm{CNF} / \mathrm{MnO}$ film reveal a homogeneous distribution of $\mathrm{C}, \mathrm{O}$ and $\mathrm{Mn}$ elements. The CNFs matrix provides enough elasticity space for volume change of $\mathrm{MnO}$ during discharge/discharge processes. It should be concluded that carbon nanofibers in such well-designed CNF/MnO hybrid film efficiently buffer the stress of $\mathrm{MnO}$ particle during lithiation/delithiation processes.

As a comparison, pure $\mathrm{MnO}$ electrode dispersed in the binder of PVdF and conductive carbon after cycles presents pulverization and irregular crystals (Figure S3). This is a strong proof supporting the capacity fading of pure $\mathrm{MnO}$ during dozens of cycles. Figure 7 exhibits the ex-situ FESEM images of CNF/MnO electrode discharged to $0.001 \mathrm{~V}$ at the $50^{\text {th }}$ cycle. Even the crystal size of $\mathrm{MnO}$ reaches to $5.1 \mu \mathrm{m}$, the $\mathrm{MnO}$ crystals are still ordered cubic particles and separately strapped by carbon nanofibers. There are two advantages in stability appeared in the hybrid structure of $\mathrm{CNF} / \mathrm{MnO}$. Firstly, $\mathrm{CNF}$ matrix provides enough elastic space for volume change of $\mathrm{MnO}$ during discharge/discharge processes; the second, $\mathrm{MnO}$ strapped by CNFs efficiently stops the pulverization of particles and lost from the matrix. Figure 7c is a good example to show one $\mathrm{MnO}$ particle strapped by several elastic carbon nanofibers. The corresponding elemental mapping reveals a homogeneous dispersion of $\mathrm{C}, \mathrm{O}, \mathrm{Mn}$ elements and the stable hybrid structure (Figure 7d). TEM images clearly reveal the morphologies of 
$\mathrm{MnO}$ crystal and $\mathrm{CNF} / \mathrm{MnO}$ film as anode discharge for 50 cycles. The body of $\mathrm{MnO}$ is still solid crystal except a loose thin layer on the surface (Figure 7e). Furthermore, carbon nanofiber presents a little increase in diameter because CNFs also involve in the lithiation/delithiationin addition to the role as conductive matrix loading $\mathrm{MnO}$ crystals (Figure 7f).

XPS on $\mathrm{CNF} / \mathrm{MnO}$ film at the state of $50^{\text {th }}$ discharge is displayed in Figure 8. Figure 8a shows the XPS survey spectrum after different $\mathrm{Ar}^{+}$ion sputtering times. With the extending of etching time, the Mn2p peaks have been gradually strengthened to a stable state as the SEI film completely removed. Before and after $\mathrm{Ar}^{+}$etching, the main component on the surface of $\mathrm{CNF} / \mathrm{MnO}$ electrode is $\mathrm{Li}_{2} \mathrm{CO}_{3}$ presented a large Li1s peak at the binding energy of $55.0 \mathrm{eV}$ (Figure 8b). ${ }^{[27]}$ After $\mathrm{Ar}^{+}$etching for 270 seconds, a weak peak appears at the binding energy of $53.16 \mathrm{eV}$ attributed to the existence of $\mathrm{Li}_{2} \mathrm{O}$. The $\mathrm{C} 1 \mathrm{~s}$ and $\mathrm{O}$ 1s XPS from fresh $\mathrm{CNF} / \mathrm{MnO}$ film present the characteristic strong peaks (Figure 8c, 8d), for example $\mathrm{C} \mathrm{sp}^{2}$ from CNFs observed at $284.8 \mathrm{eV}$. After 50 cycles lithiation, $\mathrm{C} \mathrm{sp}{ }^{2}$ from CNF is seriously weakened but a strong $\mathrm{C} 1$ s peak is observed at $289.9 \mathrm{eV}$ attributed to the component of $\mathrm{Li}_{2} \mathrm{CO}_{3}$, owing to SEI film grown on CNF. This is the strong evidence that CNF involves in the lithiation/delithiation in addition to the role as substrate loading $\mathrm{MnO}$ and as conductive channel improving electrochemical properties.

\section{Conclusion}

In summary, the present work has demonstrated a low-cost and potentially scalable technique of synthesizing flexible CNF/MnO film as bind-free anode for LIB. In the hybrid structure of $\mathrm{CNF} / \mathrm{MnO}, \mathrm{MnO}$ particles are effectively strapped by carbon nanofibers during charge/discharge cycles. The ex-situ SEM images of CNF/MnO after 50 cycles clearly show 
the relative volume change of $\mathrm{MnO} / \mathrm{CNF}$ as anode under various discharging and charging time. The carbon nanofibers play the roles of conductive channel and confining $\mathrm{MnO}$ particles in CNFs matrix to buffer the volume change of $\mathrm{MnO}$ during lithiation/delithiation. The synthesized CNF/MnO films show a specific capacity of $823.8 \mathrm{mAh} \mathrm{g}^{-1}$ after $100^{\text {th }}$ cycle at a current density of $0.2 \mathrm{~A} \mathrm{~g}^{-1}$, and $600 \mathrm{mAh} \mathrm{g}^{-1}$ at $1 \mathrm{~A} \mathrm{~g}^{-1}$, much better than those of pure $\mathrm{MnO}$ and pure CNF. The CNF matrix provides enough elasticity space for volume change of $\mathrm{MnO}$ during discharge/discharge processes. The crystal size of $\mathrm{MnO}$, increasing during lithiation and decreasing during delithiation, has been efficiently buffered by flexible carbon nanofibers.

Our one-pot synthesis route to load metal oxide in CNF is simple and industrially scalable. This work has successfully demonstrated the potential to synthesize flexible electrode with high weight loading of metal oxide for energy storage devices.

\section{Experimental Section}

Materials Preparation: The preparing process of CNF films includes electrospinning method and carbonization of PAN. The weight of CNFs film is $2.5 \mathrm{mg} \mathrm{cm}^{-2}$ and the size of CNFs electrodes is $1 \mathrm{~cm}$ in diameter. A solution included $\mathrm{MnCl}_{2}$ and urea with weight ratio of $1.2: 1$ was added in a autoclave (the filling degree 70\%), and CNFs films were placed in the autoclave. The hydrothermal reaction was under $200{ }^{\circ} \mathrm{C}$ for $6 \mathrm{~h}$. The resulted $\mathrm{CNF} / \mathrm{MnCO}_{3}$ film was washed for several times with distilled water and ethanol, dried in vacuum at $90{ }^{\circ} \mathrm{C}$ for $12 \mathrm{~h}$. The flexible film of $\mathrm{CNF} / \mathrm{MnCO}_{3}$ was heated in $\mathrm{N}_{2}$ atmosphere at $700{ }^{\circ} \mathrm{C}$ for $3 \mathrm{~h}$, which converted to flexible $\mathrm{CNF} / \mathrm{MnO}$ film. The structure and morphologies of the as-produced $\mathrm{CNF} / \mathrm{MnO}$ are repeatable for three batches. As a comparison, the sample of pure $\mathrm{MnO}$ powder was also produced according to the previous procedure without CNF film.

Structure and Morphology Characterization: The as-synthesized products were examined by 
XRD on Rigaku diffractometer (Dmax-2200) with $\mathrm{Cu} \mathrm{K} \alpha$ radiation at $30 \mathrm{kV}$ and $30 \mathrm{~mA}$. The diffraction data was collected at each $0.02^{\circ}$ step from $10^{\circ}$ to $80^{\circ}$. The morphologies of the products were characterized by scanning electron microscopy (FE-SEM and EDX, SIGMA, ZEISS $20 \mathrm{kV}$ ), transmission electron microscopy (TEM, JEOL-2000CX, $200 \mathrm{kV}$ ) and high-resolution transmission electron microscopy (HRTEM, JEOL JEM-2010F, $200 \mathrm{kV}$ ). The elemental analysis was carried out using X-ray photoelectron spectroscopy (XPS, Thermo Scientific, Escalab250Xi, Al-Ka as radiation source). The binding energies obtained in XPS analysis were calibrated against the C1s peak that was locked at $284.6 \mathrm{eV}$. Core level peaks were deconvoluted using Gaussian-Lorentzian line shapes and Shirley background. The amounts of $\mathrm{C}, \mathrm{H}$ and $\mathrm{N}$ elements were measured with a VarioEL III elemental analyzer (Elementar, Germany). To study the morphologies and elemental state of the electrode after lithiation/delithiation, batteries were disassembled in an Ar-filled glove box. The removed electrodes were rinsed for several times with dimethyl carbonates, and then dried in Ar-filled glove box overnight.

Electrochemical measurement: The binder-free flexible film $\mathrm{CNF} / \mathrm{MnO}$ and pure carbon nanofibers film as electrode were directly assembled in a CR2016 coin cell. The coin cells (CR2016) were assembled in an Ar-filled glove box using lithium metal as the counter electrode, Celgard 2500 as the separator, and $1 \mathrm{M} \mathrm{LiPF}_{6}$ (dissolved in ethylene carbonate, dimethyl carbonate and ethyl-methyl carbonate in a $1: 1: 1$ volume ratio) as the electrolyte. Meanwhile, the comparison electrode of pure $\mathrm{MnO}$ was a mixture of $70 \mathrm{wt} \%$ as-synthesized sample, $20 \mathrm{wt} \%$ acetylene black, and $10 \mathrm{wt} \%$ polyvinylidenedifluoride (PVDF) in the presence of N-methyl pyrrolidinone (NMP). After being stirred overnight, the slurry was pasted onto a $\mathrm{Cu}$ foil, and then the electrode was dried at $120^{\circ} \mathrm{C}$ under vacuum. The working area of the electrode was set at $\Phi 1.1 \mathrm{~cm}$ and the weight of $3-4 \mathrm{mg} \mathrm{cm}^{-2}$. The galvanostatic charge and discharge cycling was studied at room temperature in the voltage range $\quad 0.001-3.0$ 
$\overline{\mathrm{V}\left(\mathrm{vs} . \mathrm{Li}^{+} / \mathrm{Li}\right) \text { at different current densities by LAND CT2001A battery testing system (Wuhan, }}$ China). Cyclic voltammetry (CV) was conducted on the CHI660E electrochemical workstation (Shanghai, China) between voltages 0.001 and $3.0 \mathrm{~V}\left(\mathrm{vs} . \mathrm{Li}^{+} / \mathrm{Li}\right.$ ) at a scan rate of $0.1 \mathrm{mV} \mathrm{s}^{-1}$. Electrochemical impedance spectroscopy (EIS) measurements were conducted using a PARSTAT2273 electrochemical workstation (Princeton Applied Research, USA), where the amplitude of the input $\mathrm{AC}$ signal was kept at $5 \mathrm{mV}$ and the frequency range was set between $10^{-2}$ and $10^{5} \mathrm{~Hz}$. The state of the cell was full discharged before EIS measurement. Galvanostatic intermittent titration technique (GITT) was conducted at room temperature in the voltage range $0.001-3.0 \mathrm{~V}\left(\mathrm{vs} . \mathrm{Li}^{+} / \mathrm{Li}\right)$.

\section{Supporting Information}

Supporting Information is available from the Wiley Online Library or from the author.

\section{Acknowledgments}

The authors acknowledge the support from the National Natural Science Foundation of China (Grant No. 51172032), Natural Science Foundation of Jiangsu Province of China (Grant No. BK20141229, BK20160404).

Received: ((will be filled in by the editorial staff)) Revised: ((will be filled in by the editorial staff)) Published online: ((will be filled in by the editorial staff))

\section{References}

[1] a) D. Larcher, J. M. Tarascon, Nat. Chem. 2015, 7, 19; b) R. Noorden, Nature. 2014, 507, 26; c) J. B. Goodenough, K. S. Park, J. Am. Chem. Soc. 2013, 135, 1167.

[2] Z. B. Yang, J. Ren, Z. T. Zhang, X. L. Chen, G. Z. Guan, L. B. Qiu, Y. Zhang, H. S. 
Peng, Chem. Rev. 2015, 115, 5159.

[3] a) C. Z. Yuan, H. B. Wu, Y. Xie, X. W. Lou, Angew. Chem. Int. Ed. 2013, 52, 2; b) P. Poizot, S. Laruelle, S. Grugeon, L. Dupont, J. M. Tarascon, Nature. 2000, 407, 496; c) M. V.Reddy, G. V.SubbaRao, B. V.R. Chowdari, Chem. Rev. 2013, 113, 5364; c) Y.M. Sun, X. L. Hu, W. Luo, Y.H. Huang, J. Mater. Chem. 2012, 22, 19190; d) X. Gu, L. Chen, Z. C. Ju, H. Y.Xu, J. Yang, Y. T. Qian, Adv. Funct. Mater. 2013, 23, 4049; e) X. Gu, J. Yue, L. J. Li, H. T. Xue, J. Yang, X. B. Zhao. Electrochim. Acta 2015, 184, 250.

[4] a) J. C. Guo, Q. Liu, C. S. Wang, M. R. Zachariah, Adv. Funct. Mater. 2012, 22, 803; b) G. Yang, Y. H. Li, H. M. Ji, H. Y. Wang, P. Gao, L. Wang, H. D. Liu, J. Pinto, X. F. Jiang, J. Power Sources. 2012, 216, 353; c) Q. Sun, Z.J. Sun, Z. J. Zhang, Q. Yu, Q. Yan, J. Y. Zhang, Y. Yu, B. Xiang, ACS Appl. Mater. Interfaces. 2016, 10, 6303. d) Y. M. Sun, X. L. Hu, W.Luo, F. F. Xia, Y. H. Huang. Adv. Funct. Mater. 2013, 23, 2436; e) W. Luo, X. L. Hu, Y.M. Sun, Y.H. Huang. ACS Appl. Mater. Interfaces 2013, 5, 1997.

[5] a) Y. Xia, Z. Xiao, X. Dou, H. Huang, X. H. Lu, R. J. Yan, Y.P. Gan, W. J. Zhu, J. P. Tu, W. K. Zhang, X. Y. Tao, ACS Nano. 2013, 7, 7083; b) L. Wang, Y. H. Li, Z. D. Han, L. Chen, B. Qian, X. F. Jiang, J. Pinto, G. Yang, J. Mater. Chem. A. 2013, 29, 8385; c) S. B. Wang, Y.L. Xing, C. L. Xiao, H. Z. Xu, S. C. Zhang, J. Power Sources. 2016, 307, 11; d) L. Ji, X. Zhang; Electrochem. Commun. 2009, 11, 795. e) T. Z. Yuan, Y. Z. Jiang, W. P. Sun, B. Xiang, Y. Li, M. Yan, B. Xu, S. X. Dou; Adv. Funct. Mater. 2016, 26, 2198; f) S. B. Wang, Y.L. Xing, C. L. Xiao, H. Z. Xu, S. C. Zhang; J. Power Sources 2016, 307, 11. [6] a) J. W. Qin, Q. Zhang, Z. Y. Cao, X. Li, C. W. Hua, B. Q. Wei, Nano. Energy.2013, 2, 733; b) L. F. Chen, Z. H. Huang, H. W. Liang, Q. F. Guan, S. H. Yu, Adv. Mater. 2013, 25, 4746.

[7] a) C. Wang, W. Wan, Y.H. Huang, J. T. Chen, H. H. Zhou, X. X. Zhang, Nanoscale. 2014, 6, 5351; b) C. Z. Yuan, L. Yang, L. R. Hou, L. F. Shen, X.G. Zhang, X. W. Lou, Energy 
Environ. Sci. 2012, 5, 7883; c) L. Yu, G. Q. Zhang, C. Z. Yuan, X.W. Lou, Chem. Commun. 2013, 49, 137.

[8] a) R. J. Chen, T. Zhao, W.P. Wu, F. Wu, J.Q. Li, R. Xu, H.M. Wu, H. M. Albishri, A. S. Al-Bogami, D. A. El-Hady, J. Lu, K. Amine, Nano Lett. 2014, 14, 5899; b) Y. R. Zhong, M. Yang, X. L. Zhou, Y. T. Luo, J.P. Wei, Z. Zhou, Adv. Mater. 2015, 27, 806; c) Z. P. Luo, Q. Z. Xiao, G. T. Lei, Z. H. Li, C. J. Tang, Carbon. 2016, 98, 373.

[9] a) W. Li, M. Li, M. Wang, L. Zeng, Y. Yu, Nano Energy. 2015, 13, 693; b) B. Zhang, F. Y. Kang, J. M. Tarascon, J. K. Kim, Prog. Mater. Sci. 2016, 76, 319.

[10] a) H. Y. Wang, H. Q. Huang, L. Chen, C. G. Wang, B. Yan, Y. T. Yu, Y. Yang, ACS. Sustainable Chem. Eng. 2014, 2, 2310; b) B. Liu, X. L. Hu, H. H. Xu, W. Luo, Y.M. Sun, Y. H. Huang. Sci. Rep. 2014, 4, 4229; c) J. G. Wang, Y. Yang, Z, H. Huang, F. Y. Kang, Electrochim. Acta 2015, 170, 164.

[11] W. Li, M. Li, M. Wang, L. Zeng, Y. Yu, Nano Energy. 2015, 13, 693.

[12] Y. Mao, H. Duan, B. Xu, L. Zhang, Y. S. Hu, C. C. Zhao, Z. X. Wang, L. Q. Chen, Y. S. Yang, Energy Environ. Sci. 2012, 5, 7950.

[13] a) C. Wang, W. Wan, Y.H. Huang, J. T. Chen, H. H. Zhou, X. X. Zhang, Nanoscale. 2014, 6, 5351; b) C. Z. Yuan, L. Yang, L.R. Hou, L.F. Shen, X.G. Zhang, X. W. Lou, Energy Environ. Sci. 2012, 5, 7883; c) L. Yu, G. Q. Zhang, C. Z. Yuan, X. W. Lou, Chem. Commun.2013, 49, 137; d) C. X. Yang, Q. M. Gao, W. Q. Tian, Y. L. Tan, T. Zhang, K. Yan, L. H. Zhua, J. Mater. Chem. A 2, 2014, 19975.

[14] X. X. Gu, J. Yue, L. Chen, S. Liu, H. Y. Xu, J. Yang, Y. T. Qian, X. B. Zhao,J. Mater. Chem. A. 2015, 3, 1037.

[15] Y.Xiao, M. Cao, ACS Appl. Mater. Interfaces. 2015, 7, 12840.

[16] D. Liu, H. Lu, H. Yang, X. L. Wu, B. H. Hou, F. Wan, S. D. Bao, Q. Y. Yan, H. M. Xie, R. S. Wang, J. Mater. Chem. A 2015, 3, 19738.

[17] a) M. M. Yang, Y. R. Zhong, X. L. Zhou, J. J. Ren, L.W. Su, J. P. Wei, Z. Zhou, J. Mater. 
Chem. A. 2, 2014, 12519; b) D. Hulicova-Jurcakov, M. Seredych, G. Q. Lu, T. J. Bandosz, Adv. Funct. Mater. 2009, 19, 438.

[18] Y. Xiao, X. Wang, W. Wang, D. Zhao, M. Cao, ACS Appl. Mater. Interfaces. 2014, 6, 2051.

[19] J. Collins, G. Gourdin, M. Foster, D. Y.Qu, Carbon 2015, 92, 193.

[20] X. W. Li, D. Li, L. Qiao, X. H. Wang, X.L. Sun, P. Wang, D.Y. He, J. Mater. Chem. 2012, $22,9189$.

[21] B. Sun, Z. Chen, H.-S. Kim, H. Ahn, G. Wang, J. Power Sources. 2011, 196, 3346.

[22] W. Weppner, R. A. Huggins, J. Electrochem. Soc. 1997, 124, 1569.

[23] Y.Liu, N. Zhang, L. Jiao, J. Chen, Adv. Mater. 2015, 27, 6702.

[24] J. Maier, Nat. Mater, 2005, 4, 805.

[25] a) K.F. Zhong, X. Xia, B. Zhang, H. Li, Z.X. Wang, L.Q. Chen, J. Power Sources 2010, 195, 3300; b) K.F. Zhong, B. Zhang, S.H. Luo, W. Wen, H. Li, X.J. Huang, L.Q. Chen, J. Power Sources 2011, 196, 6802; c) X.W. Li, D. Li, L. Qiao, X.H. Wang, X.L. Sun, P. Wang, D.Y. He, J. Mater. Chem. 2012, 22, 9189. c) J. Zhang, R. Wang, X. C. Yang, W. Lu, X. D. Wu, X. P. Wang, H. Li, L. W. Chen, Nano Lett. 2012, 12, 2153.

[26] M. R. Busche, T. D. M. Schneider, M. L. Rechi, H. Sommer, D. A.Weber, M. Falk J. Janek, Nat. Chem. 2016, 8, 426.

[27] K. Edströma, M. Herstedta, D. P. Abraham, J. Power Sources. 2006, 153, 380. 
Table 1 Impedance parameters fitted using equivalent circuit for $\mathrm{CNF} / \mathrm{MnO}$ and pure $\mathrm{MnO}$ electrodes at the state of the $4^{\text {th }}$ and $20^{\text {th }}$ discharge.

\begin{tabular}{lcccccc}
\hline Samples & $\mathrm{R}_{\mathrm{s}} / \Omega$ & $\mathrm{R}_{\text {sei }} / \Omega$ & $\mathrm{R}_{\mathrm{e}} / \Omega$ & $\mathrm{R}_{\mathrm{ct}} / \Omega$ & $\mathrm{W}-\mathrm{r} / \Omega$ & $x^{2} / 10^{-4}$ \\
\cline { 2 - 7 } $\mathrm{CNF} / \mathrm{MnO} 4^{\text {th }}$ & 6.384 & 8.704 & 27.16 & 27.42 & 96.1 & 1.6 \\
$\mathrm{MnO}^{\text {th }}$ & 2.989 & 8.596 & 35.68 & 96.98 & 183.6 & 2.9 \\
$\mathrm{CNF} / \mathrm{MnO} 20^{\text {th }}$ & 3.418 & 12.73 & 9.614 & 40.9 & 103.6 & 1.2 \\
$\mathrm{MnO} 20^{\text {th }}$ & 2.094 & 84.1 & 138.5 & 3660 & 200.6 & 1.9 \\
\hline
\end{tabular}




\section{Figure captions}

Figure 1 SEM images of $\mathrm{MnO}\left(\mathrm{a}, \mathrm{a}^{\prime}\right)$ and $\mathrm{CNF} / \mathrm{MnO}\left(\mathrm{b}, \mathrm{b}^{\prime}\right)$. The insets are the digital photos of both samples, XRD patterns of $\mathrm{MnO}$, pure CNF and the composite CNF/MnO (c), and the EDS mapping images of $\mathrm{CNF} / \mathrm{MnO}\left(\mathrm{c}^{\prime}\right)$.

Figure 2 Cyclic voltammetry profiles of flexible film $\mathrm{CNF} / \mathrm{MnO}$ between 0 and $3 \mathrm{~V}$ at a scan rate of $0.1 \mathrm{mV}$ $\mathrm{s}^{-1}$ (a). GITT curves (b), and diffusion coefficients of $\mathrm{Li}^{+}$in pure $\mathrm{MnO}, \mathrm{CNF} / \mathrm{MnO}$ at discharge (b) and charge (c) processes, respectively.

Figure 3 The initial charge/discharge profiles (a), cycling life and the corresponding Columbic efficiencies (b) of $\mathrm{MnO}, \mathrm{CNF} / \mathrm{MnO}$ and $\mathrm{CNF}$ carried out under the current density of $0.2 \mathrm{Ag}^{-1}$.

Figure 4 EIS fitted profiles of $\mathrm{MnO}$ and CNF/MnO electrodes at the $4^{\text {th }}$ discharge state (a) and the $20^{\text {th }}$ discharge state (b). The inset in (a) is the schematic conductive channel for electrons and lithium ions, and the inset in (b) is the equivalent circuit fitting EIS data. Hollow dots represent the experimental data and the line represents the fitted data.

Figure 5 Low magnified (the $1^{\text {st }}$ line) and high magnified (the $2^{\text {nd }}$ line) SEM images,nd elemental mapping (the $3^{\text {rd }}$ line) of the flexible electrode $\mathrm{CNF} / \mathrm{MnO}$ at the state of discharging $1 \mathrm{~h}(\mathrm{a}), 3 \mathrm{~h} \mathrm{(b),} 9 \mathrm{~h}$ (c), and $12 \mathrm{~h}$ (d), respectively.

Figure 6 Low magnified (the $1^{\text {st }}$ line) and high magnified (the $2^{\text {nd }}$ line) SEM images, and elemental

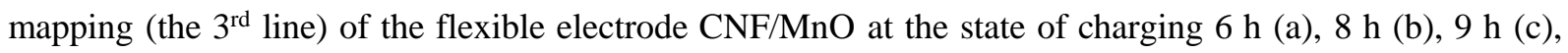
and $11 \mathrm{~h}(\mathrm{~d})$, respectively.

Figure 7 Low magnified (a) and high magnified (b) SEM images, elemental mapping (c, d), and TEM images (e, $\mathrm{f}$ ) of the flexible electrode $\mathrm{CNF} / \mathrm{MnO}$ at the state of $50^{\text {th }}$ discharge.

Figure 8 XPS wide scan survey of an electrode $\mathrm{CNF} / \mathrm{MnO}$ at the state of $50^{\text {th }}$ discharging after $\mathrm{Ar}^{+}$etching for $0-270 \mathrm{~s} \mathrm{(a).} \mathrm{XPS} \mathrm{spectrum} \mathrm{Li} \mathrm{1s} \mathrm{(b),} \mathrm{C} \mathrm{1s} \mathrm{(c),} \mathrm{and} \mathrm{O} \mathrm{1s} \mathrm{(d)} \mathrm{without} \mathrm{Ar}^{+}$etching and with $270 \mathrm{~s} \mathrm{Ar}^{+}$ etching. 


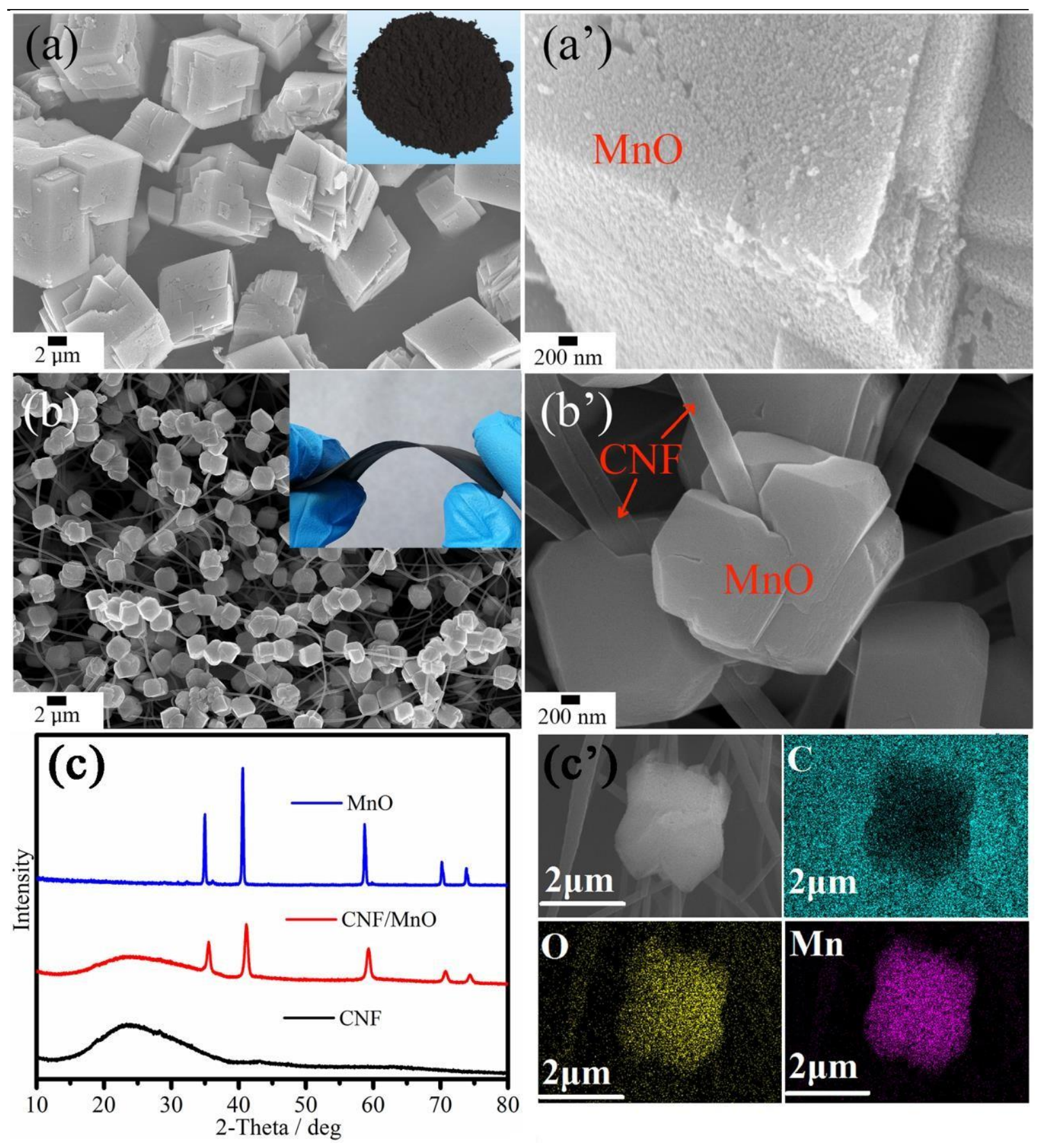

Figure 1 SEM images of $\mathrm{MnO}\left(\mathrm{a}, \mathrm{a}^{\prime}\right)$ and $\mathrm{CNF} / \mathrm{MnO}(\mathrm{b}, \mathrm{b}$ '). The insets are the digital photos of both samples, XRD patterns of $\mathrm{MnO}$, pure $\mathrm{CNF}$ and the composite $\mathrm{CNF} / \mathrm{MnO}$ (c), and the EDS mapping images of $\mathrm{CNF} / \mathrm{MnO}\left(\mathrm{c}^{\prime}\right)$. 

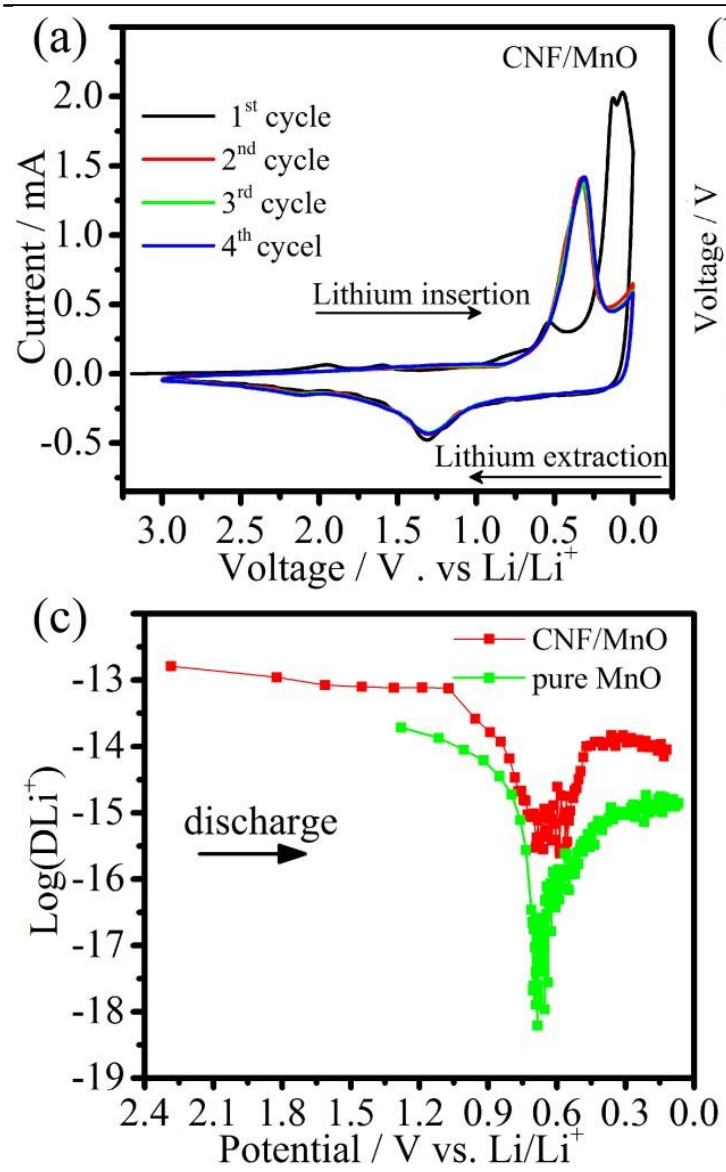
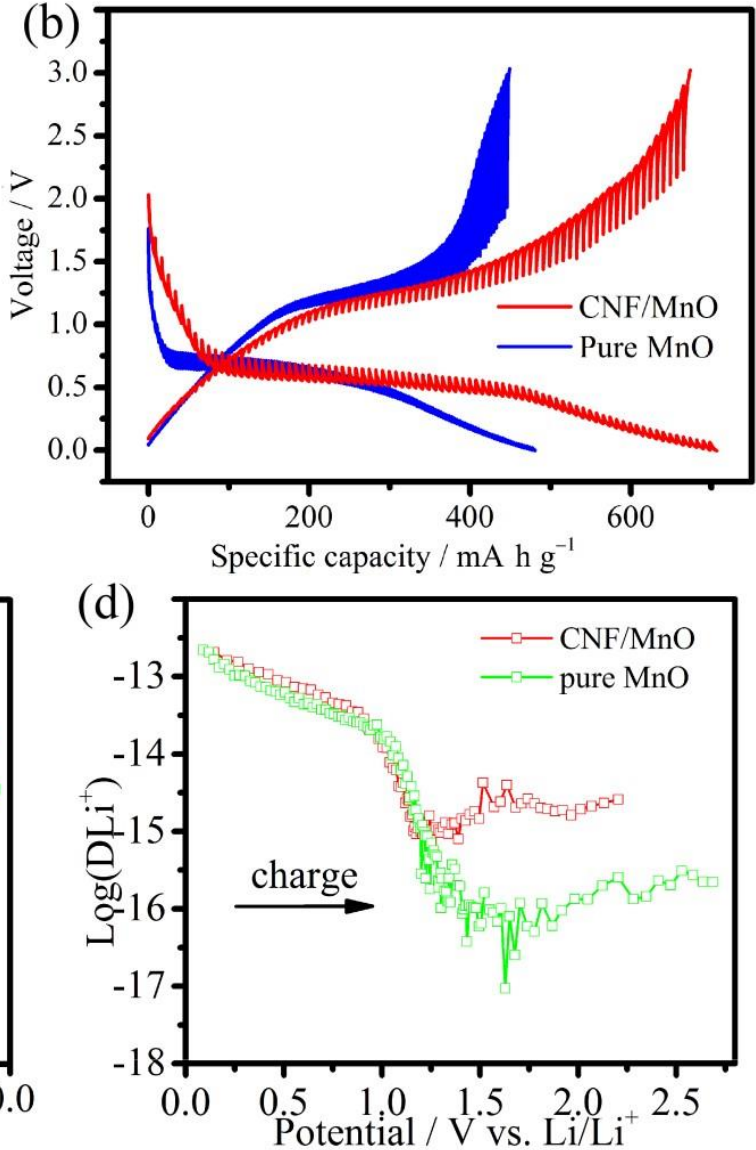

Figure 2 Cyclic voltammetry profiles of flexible film $\mathrm{CNF} / \mathrm{MnO}$ between 0 and $3 \mathrm{~V}$ at a scan rate of $0.1 \mathrm{mV} \mathrm{s}^{-1}$ (a). GITT curves (b), and diffusion coefficients of $\mathrm{Li}^{+}$in pure $\mathrm{MnO}$, $\mathrm{CNF} / \mathrm{MnO}$ at discharge (c) and charge (d) processes, respectively.
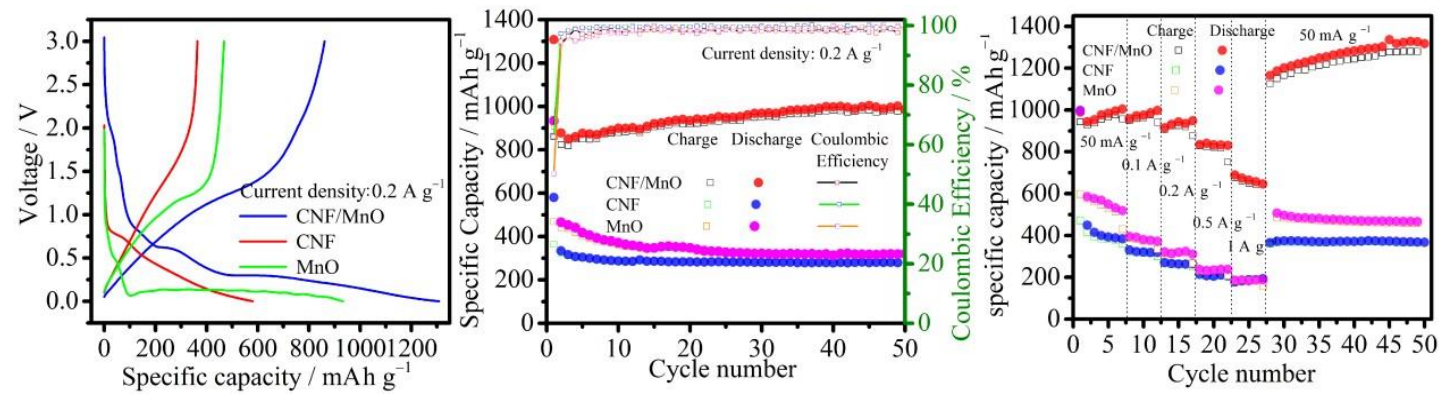

Figure 3 The initial charge/discharge profiles (a), cycling life and the corresponding Columbic efficiencies (b) of $\mathrm{MnO}, \mathrm{CNF} / \mathrm{MnO}$ and $\mathrm{CNF}$ carried out under the current density of $0.2 \mathrm{Ag}^{-1}$. 

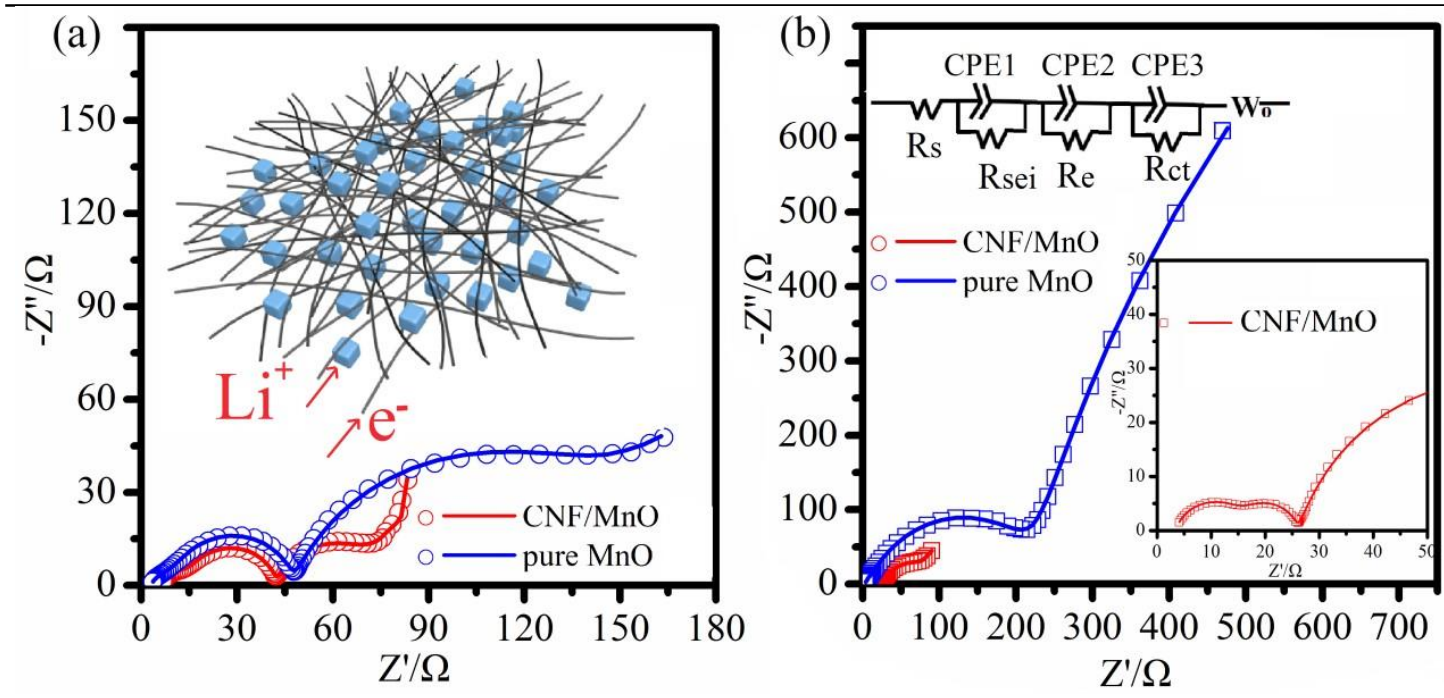

Figure 4 EIS fitted profiles of $\mathrm{MnO}$ and $\mathrm{CNF} / \mathrm{MnO}$ electrodes at the $4^{\text {th }}$ discharge state (a) and the $20^{\text {th }}$ discharge state (b). The inset in Figure $4 \mathrm{a}$ is the schematic conductive channel for electrons and lithium ions, and the insets in Figure 4bare the equivalent circuit and the enlarged Nyquist plot of $\mathrm{CNF} / \mathrm{MnO}$. Hollow dots represent the experimental data and the lines represent the fittings. 


\section{Discharge \\ 9h}

14hTime
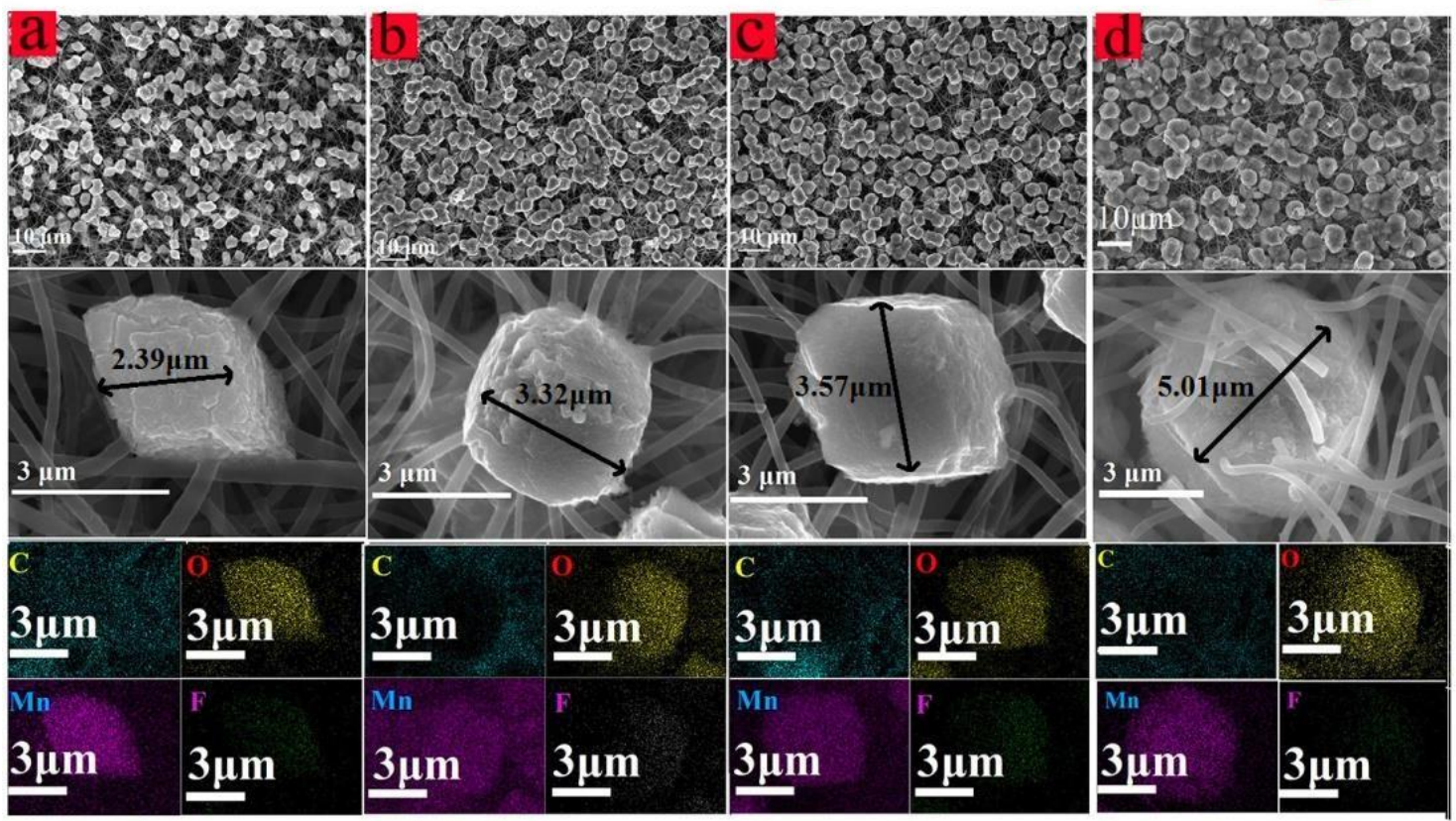

Figure 5 Low magnified (the $1^{\text {st }}$ line) and high magnified (the $2^{\text {nd }}$ line) SEM images,and elemental mapping (the $3^{\text {rd }}$ line) of the flexible electrode $\mathrm{CNF} / \mathrm{MnO}$ at the state of discharging $1 \mathrm{~h} \mathrm{(a),} 3 \mathrm{~h}(\mathrm{~b}), 9 \mathrm{~h}(\mathrm{c})$, and $12 \mathrm{~h}(\mathrm{~d})$, respectively. All the cells are operated at $50 \mathrm{~mA} \mathrm{~g}^{-1}$. 


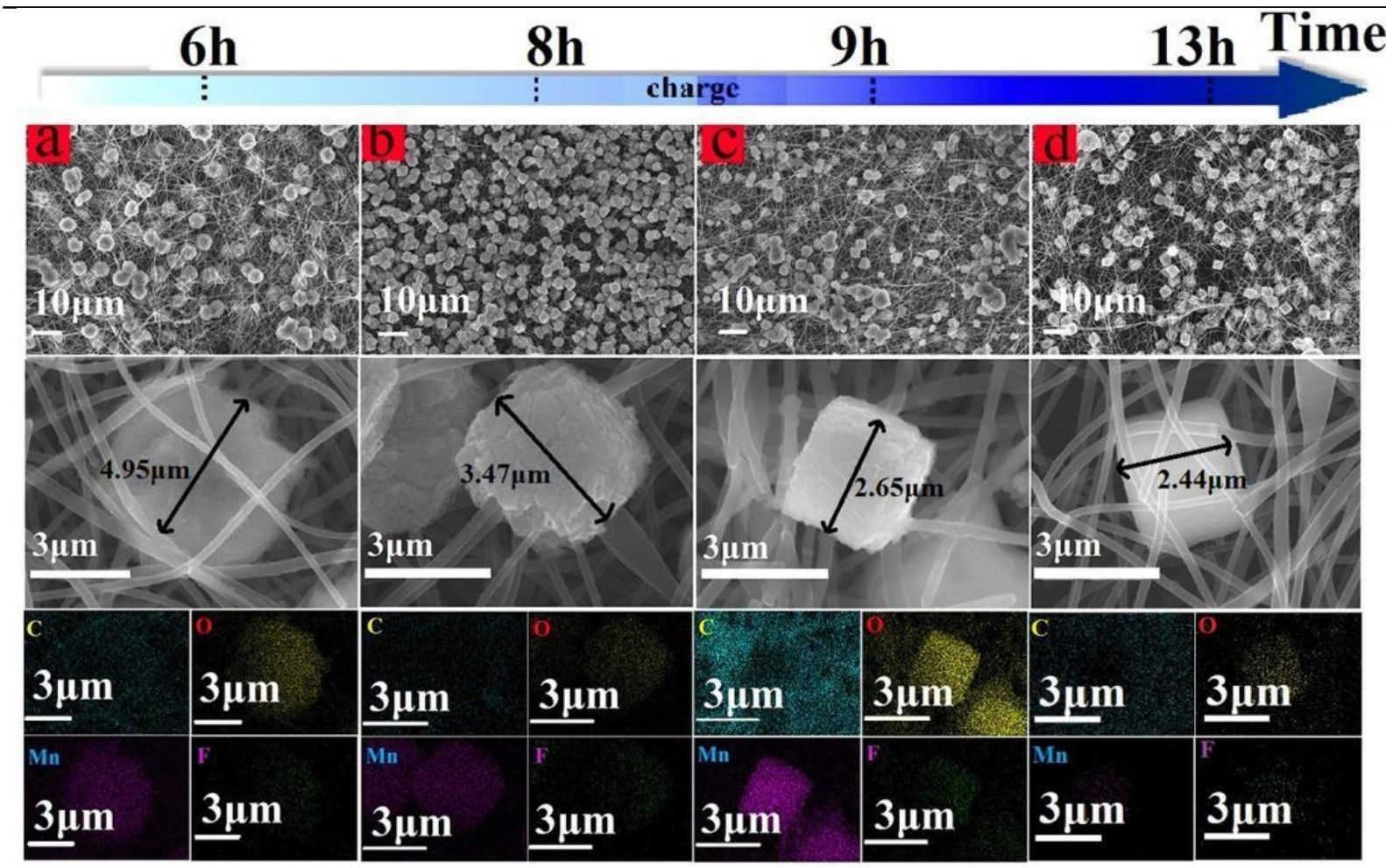

Figure 6 Low magnified (the $1^{\text {st }}$ line) and high magnified (the $2^{\text {nd }}$ line) SEM images, and elemental mapping (the $3^{\text {rd }}$ line) of the flexible electrode $\mathrm{CNF} / \mathrm{MnO}$ at the state of charging $6 \mathrm{~h}$ (a), $8 \mathrm{~h}(\mathrm{~b}), 9 \mathrm{~h}(\mathrm{c})$, and $11 \mathrm{~h}(\mathrm{~d})$, respectively. All the cells are operated at $50 \mathrm{~mA} \mathrm{~g}^{-1}$. 


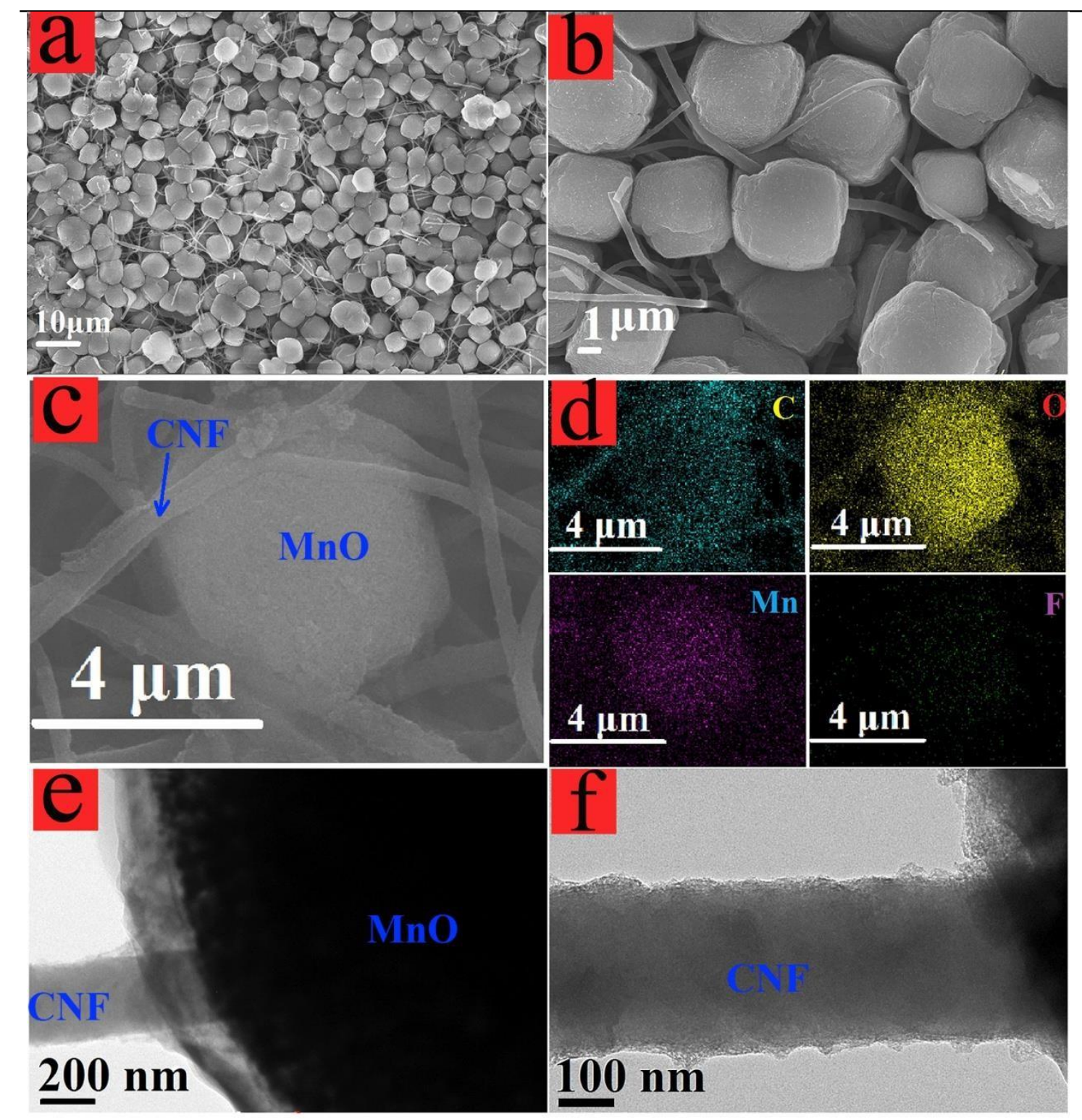

Figure 7 Low magnified (a) and high magnified (b) SEM images, elemental mapping (c, d), and TEM images $(\mathrm{e}, \mathrm{f})$ of the flexible electrode $\mathrm{CNF} / \mathrm{MnO}$ at the state of $50^{\text {th }}$ discharge. 

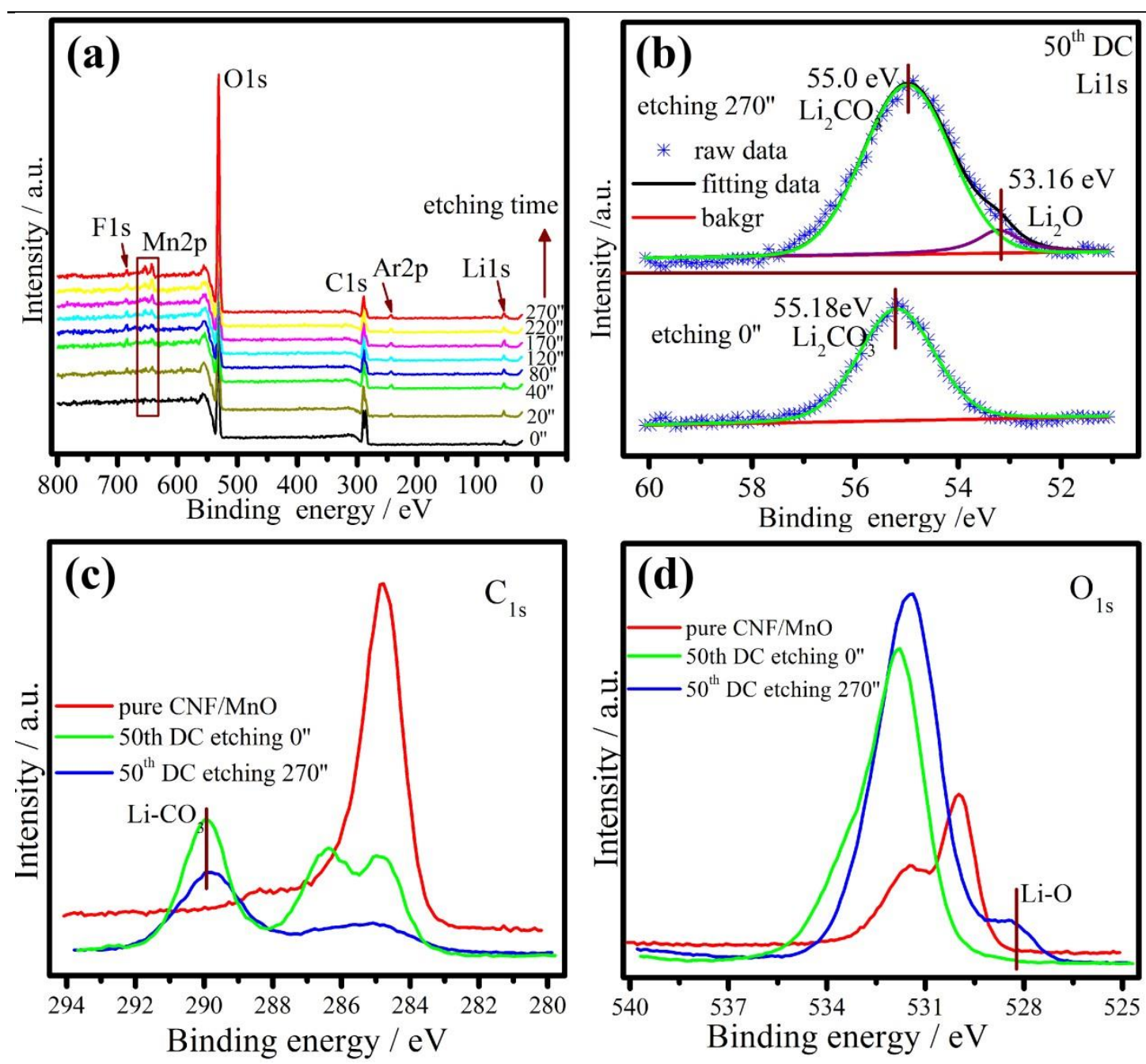

Figure 8 XPS wide scan survey of an electrode $\mathrm{CNF} / \mathrm{MnO}$ at the state of $50^{\text {th }}$ discharging after $\mathrm{Ar}^{+}$etching for $0-270 \mathrm{~s}$ (a). XPS spectrum Li 1s (b), C 1s (c), and O 1s (d) without $\mathrm{Ar}^{+}$ etching and with $270 \mathrm{~s} \mathrm{Ar}^{+}$etching. 